\title{
The Herrnhuter Brethren in Search of Ethiopian Christianity: A Letter to Abunä Yohannnəs III (1756)
}

\author{
Lina Elhage-Mensching
}

\section{Introduction}

This article positions itself within the perspective of a small community in the Europe of the 18th century with a specific view on Ethiopia, which led it to build a whole discourse on an Ethiopian identity. More precisely, the article focuses on one of the sporadic interactions between German Protestants, namely the Herrnhuter Brethren, and the Ethiopian Church as early as the 18th century, testified in letters that are kept in the archives of the Herrnhuter Brethren in Germany. The core of this article is the commented edition and translation of one of these letters, a letter of recommendation from the Coptic Orthodox Pope Markos VII (r. 1745-1769), patriarch of Alexandria, to the metropolitan of Ethiopia, Abunä Yohanannəs III (r. 1744-1761), ${ }^{1}$ written in Arabic and dating from 1756 .

It was in 1722 that protestant refugees, descendants of the Unity of Brethren from Moravia, a region in what is today the Czech Republic, fleeing on-going persecution after the Counter-reformation, sought refuge on the estate of a noble Pietist, Count Nikolaus von Zinzendorf, in Lutheran Saxony. With his help, they developed the settlement that they called Herrnhut. They were soon joined by other refugees from Moravia and Bohemia as well as by Lutheran Germans. Count von Zinzendorf very soon became involved in their communal work and five years later, in 1727, with more than 200 people living in Herrnhut, the Herrnhuter Brüdergemeine, a protestant evangelical church was founded. ${ }^{2}$

1 Cf. Osvaldo Raineri, "Yoḥannəs [III]," in EAe 5 (2014): 71-72.

2 For these and other general details on the Herrnhuter Brethren mentioned throughout this article, see, among others: Taylor Hamilton and Kenneth Hamilton, History of the Moravian Church, the Renewed Unitas Fratrum (Bethlehem, PA: Interprovincial Board of Christian Education Moravian Church in America, 1967); Joseph Hutton, A History of the Moravian Missions (London: Moravian Publ. Office, 1922); Joseph Hutton, A History of the Moravian Church, and ed. (London: Moravian Publ. Office, 1909). These works can also be used as reference works on the history of this community. 
The movement soon extended beyond the boundaries of Herrnhut and, in 1732, the first two missionaries set out from Herrnhut to the Danish West Indies. This was just a start. Within two decades, more than 70 missionaries had been sent across the world from a congregation of merely 6oo members. ${ }^{3}$

Herrnhut still exists today and still possesses a huge collection of documents from the past three centuries. An edition project funded by the German Research Foundation (DFG) and headed by Martin Tamcke, ${ }^{4}$ mainly based on a corpus of documents preserved in the archives at Herrnhut, resulted in a series of publications which unveiled the vast extent of the first interactions between members of that community and the communities of various confessions in the Middle East. The publications comprised the edition of diaries and letters covering the period from 1769 to 1783 that testified to the activities of those German protestant missionaries in Egypt during the 18th century. ${ }^{5}$ The archives at Herrnhut also preserved Arabic manuscripts of the period preceding $1769{ }^{6}{ }^{6}$ which were not included in the mentioned project and which I edited for the first time. ${ }^{7}$

This article is organized as follows: After a brief presentation of the Herrnhuter Brethren, I will first, in section 2, briefly refer to the vision of their leader with respect to the country he called "Abyssinia," and then to the means undertaken by the Herrnhuter in view of achieving their goal, namely to establish a contact with the Ethiopian Christians by actually travelling there. In section 3 , I will present and discuss my first edition of the above-mentioned letter of

3 Cf. John Choules and Thomas Smith, The Origin and History of Missions. Compiled and Arranged from Authentic documents. Vol. 1 (Boston: S. Walker, 1832), 41.

4 Research Project "Edition der Quellen zu Ägypten der Herrnhuter Brüderunität" (2006-2012), URL: http://gepris.dfg.de/gepris/projekt/30265927 (o8.o1.2019).

5 The publications include Arthur Manukyan, Konstantinopel und Kairo. Die Herrnhuter Brüdergemeine im Kontakt zum Ökumenischen Patriarchat und zur Koptischen Kirche. Interkonfessionelle und interkulturelle Begegnungen im 18. Jahrhundert (Würzburg: Ergon Verlag, 2010); Martin Tamcke and Arthur Manukyan, ed., Herrnhuter in Kairo. Die Tagebücher 1769-1783 (Würzburg: Ergon Verlag, 2012); Martin Tamcke, Arthur Manukyan and Christian Mauder, ed., Die arabischen Briefe aus der Zeit der Herrnhuter Präsenz in Ägypten 1770-1783 (Würzburg: Ergon Verlag, 2012).

6 Under R.17.B- "Beziehungen zur Orthodoxen und Koptischen Kirche," o7.b and o7.c.

7 The critical edition and translation of the three Arabic letters predating 1769, can be found in Lina Elhage-Mensching, Pope Mark VII. Arabic Letters to Count von Zinzendorf and Yohannes III, Metropolitan of Abyssinia, with the 'Sermon on the True Faith' in an Appendix (BadenBaden: Ergon, 2020). Also see: Lina Elhage-Mensching, "Wie kommt man nach Äthiopien? Patriarch Markos viI. (r. 1745-1769), Abuna Johannes III. (r. 1747-1761) und Ireneos Hocker (1713-1782)," in Imaginiert und real, erschaut und erdacht. Literarische Werke von und über Christen in Ägypten, ed. Martin Tamcke and Heike Behlmer (Wiesbaden: Harrassowitz, 2017), $79-88$. Section 2 is partly based on that article. 
recommendation, which the Herrnhuter Brethren member who was in charge of the mission received from the Coptic Orthodox Pope Markos vil and carried with him aiming to give it to the metropolitan of Ethiopia. I will conclude with a few remarks on the importance of this correspondence in providing a small piece of testimony to the immense interest in establishing contact with the Ethiopian Christianity on behalf of a small community of Pietists as early as the 18 th century.

\section{$2 \quad$ The Failed Herrnhuter Mission to Ethiopia}

\subsection{An Ethiopian Identity as Seen from Abroad in the 18th Century}

To understand the context of the Arabic letters at issue and, in particular, the one that I will present and discuss in section 3 , a few words about the vision of Count Zinzendorf are due. He hoped that Herrnhut would be the center of a movement that would unite the various Christian denominations and he soon became the leader of the community and the renewer of the Unity of Brethren. ${ }^{8}$ According to the Periodical Accounts relating to the Missions of the Church of the United Brethren, the missionaries were sent out to spread a message of unity involving all Christians in one universal mission. Zinzendorf wished to establish a "spiritual connection between the Unity of the Brethren and other divisions of the Church of Christ on earth."9 His knowledge of the existence of a Christian church in Egypt and especially in Ethiopia, with whom a contact might be established, led him to entertain the idea to send "Brethren to visit the distant and hitherto nearly inaccessible Christians in Egypt and Abyssinia."10 This must be seen in connection with early Christianity and the context already mentioned in the Acts 8:27: the Ethiopian eunuch, treasurer of Queen Candace, who converted to Christianity. To Zinzendorf, Ethiopia was a truly Christian country where Christianity had spread as early as the fourth century when the king of Axum had established it as the court religion. It seems that Zinzendorf saw the Ethiopian faith as an expression of the Urchristentum, the original Christianity which had preserved a kind of religious purity over the centuries. ${ }^{11}$

8 Cf. Hutton, A History of the Moravian Church, 171.

9 Cf. Brethren's Society for the Furtherance of the Gospel, ed., Periodical Accounts relating to the Missions of the Church of the United Brethren established among the Heathen. Vol. 12 (London: John Marshall, 1831), 97.

10 Ibid.

11 Cf. Theodor Bechler, Die Herrnhuter in Ägypten. Evangelisation und Mission der Herrnhuter Brüder in Ägypten im 18. Jahrhundert und ihr Vorstoß nach Abessinien (Herrnhut:Verlag der Missionsbuchhandlung, 1936), 11. 


\subsection{Overview of the Ethiopian Mission}

Knowing that the Coptic Church was present in Egypt and Ethiopia and that the patriarch of the Coptic Church was also the patriarch of Ethiopia, ${ }^{12}$ Count von Zinzendorf thought that to reach Ethiopia, the Brethren should first ask the Coptic patriarch in Cairo for a letter of recommendation to the metropolitan of Ethiopia. ${ }^{13}$ Zinzendorf therefore sent the physician and member of the Brethren Friedrich Wilhelm Hocker to Egypt in $175^{2}$ with a letter of introduction addressed to the Coptic patriarch ${ }^{14}$ and instructions to keep his eyes on Ethiopia. ${ }^{15}$

Hocker first reached Cairo at the end of August 1752. There he started practicing as a physician, further learning Arabic and gathering information relative to Ethiopia. In a conversation with a native of Ethiopia, he was informed that the "Emperor wished to introduce Europeans into his territories, especially such as were skillful artisans."16 He was also informed that the country could be best reached by travelling down the Red Sea from Suez to Ğidda and Mușawwa'. There, from a place not far from Muṣawwa', there was a caravan travelling periodically to Gondär, the capital of the kingdom of Ethiopia. ${ }^{17}$

Hocker himself reports that by the end of November 1753, he had made himself "sufficient master of the Arabic language to translate the letter addressed by Count Zinzendorf to the Coptic Patriarch," to pay him a first visit and to inform him of his wish to reach Ethiopia and his hope to be recommended by him. ${ }^{18}$ But during Hocker's first stay in Egypt from $175^{2}$ to 1755 , the patriarch only gave him a reply to the letter of Count Zinzendorf. ${ }^{19}$ This letter is a testimony of the first ever contact between the patriarch of the Copts and the Herrnhuter and

12 Further asserted in the Fotha nägäśt: "42. As for the Ethiopians, a patriarch shall not be appointed from among their learned men, nor can they appoint one by their own will. Their metropolitan is subject to the holder of the See of Alexandria, who is entitled to appoint over them a chief who hails from his region and is under his jurisdiction." Peter Strauss, ed., The Fetha Nagast. The Law of Kings, trans. Abba Paulos Tzadua (Addis Abeba: Haile Sellassie University, 1968), 18.

13 For a detailed account of the relations between the Church of Ethiopia and the Coptic Church of Alexandria, see among others: Stuart Munro-Hay, Ethiopia and Alexandria: The Metropolitan Episcopacy of Ethiopia (Warsaw: ZAS PAN, 1997).

14 Cf. Brethren's Society for the Furtherance of the Gospel, ed., Periodical Accounts, 98.

15 Cf. Hocker's diary preserved at the Herrnhut Archives under signature R.21.A.7o.

16 Cf. Brethren's Society for the Furtherance of the Gospel, ed., Periodical Accounts, 102.

17 Cf. Bechler, Die Herrnhuter in Ägypten, 19; Brethren's Society for the Furtherance of the Gospel, ed., Periodical Accounts, 98-102.

18 Cf. Hutton, A History, 160-161; Brethren's Society for the Furtherance of the Gospel, ed., Periodical Accounts, 103 .

19 Cf. ibid., 104. 
the first of three manuscripts edited, translated and commented upon in my edition project. $^{20}$

On his next trip to Cairo, in 1756, Hocker was accompanied by another member of the Brethren, named Georg Pilder. ${ }^{21}$ After a few visits to the patriarch, the latter gave Hocker the coveted letter of recommendation to the metropolitan of Ethiopia in September $175^{6}$ (the second letter manuscript of my edition project $^{22}$ and the focus of my article, see section 3 ).

\subsection{The Failure of the Mission to Ethiopia}

While waiting for the opportunity to travel to Ethiopia, the Brethren visited the patriarch on more than one occasion. On their last visit before setting off to Suez, in September 1758, the patriarch gave Hocker a letter addressed to Count von Zinzendorf. This is the third manuscript of my edition project, only preserved in copies at Herrnhut. ${ }^{23}$

Eventually heading to Ethiopia, the two brethren left Cairo on the 22nd of September $175^{8,24}$ arrived at Suez on the 27 th of September and waited a few days to be able to embark on a Turkish vessel on the 9 th of October 1758, so as to reach Ğidda and Musawwa' and from there to travel by land to Ethiopia. On the way from Suez to Ğidda, they stopped twice and after a voyage of eleven days, the ship anchored near the coast of the island of Hassān. There, it got bogged down during a night storm and broke. Finally taken ashore two days later, Hocker and Pilder had lost most of their luggage, clothes and money, they had to remain another 19 days before being able to take a ship and reach the port of Ğidda (through Yanbu', 12-19 November) on the 3oth of November $1758 .^{25}$

20 Cf. Elhage-Mensching, Pope Mark VII, 38-41. The letter is preserved at the Herrnhut Archives under signature R.17.B.7.b.2.

21 Cf. Bechler, Die Herrnhuter in Ägypten, 20-23; David Cranz, Alte und neue Brüder-Historie oder kurz gefaßte Geschichte der evangelischen Brüder-Unität in den älteren Zeiten und insonderheit in dem gegenwärtigen Jahrhundert (Barby: Laux, 1772), 6oo, 675; Manukyan, Konstantinopel und Kairo, 293.

22 Cf. Elhage-Mensching, Pope Mark VII, 44-49. The letter is preserved at the Herrnhut Archives under signature R.17.B.7.b.3.

23 Cf. Elhage-Mensching, Pope Mark VII, 54-57. The copies are preserved at the Herrnhut Archives under signature R.17.B.7.b.4. For some further information, see section 4 of this article.

24 Cf. Bechler, Die Herrnhuter in Ägypten, 25; Cranz, Alte und neue Brüder-Historie, 677; Brethren's Society for the Furtherance of the Gospel, ed., Periodical Accounts, 189.

25 The details of the shipwreck and the hard conditions of the stay on the island of Hassān 
While in Ğidda, they met two Turkish merchants who told them that they had been commissioned by the regent of Ethiopia to bring a physician to Gondär as the Prime minister was very sick. This would have been a great opportunity to reach Ethiopia. "[F]or three reasons, however, Hocker declined the invitation. He had lost his medicine-chest; his friend was ill; and the Lot, when consulted, answered 'No."'26 (Casting lots was a common practice within Pietism and the Moravians used it to make or ratify decisions on all levels of Moravian life. They believed that the lot represented the true will of Christ). ${ }^{27}$ Hocker gave the merchants a letter to the Abunä of Ethiopia and told them that they would travel to Ethiopia the following year with a full medicine chest. They therefore waited for a vessel to return to Cairo, which they finally reached late in July 1759, almost one year after having left.

On their arrival, they learned that the pest had made numerous victims while they were away. Pilder, who was ill, returned to Europe. Hocker waited in Cairo for a reply from Count Zinzendorf to the last letter of the Coptic patriarch. While in Cairo, Hocker was informed of the death of Count Zinzendorf in July 176o. He finally left Cairo and returned to Europe in 1761 without having been able to reach Ethiopia.

Still, not discouraged by his previous attempts, Friedrich Hocker returned once more to Cairo in 1769, accompanied by another brother, namely Johann Danke. Whereas all the information they could gather from Ethiopia convinced them that any attempt would be unsuccessful, they decided to remain in Egypt and turn their attention to the Christians in Egypt. Hocker visited again the patriarch of the Copts. During one of his visits, he had the opportunity to meet the newly ordained metropolitan of Ethiopia, the successor of Yohannəs III, who invited him to accompany him. Yet, Hocker replied that it would be better to send younger brethren as he felt too old to undertake the trip. He remained in Cairo and attended Patriarch Markos in his sickness before he died in May 1769. Hocker, who had tried so heartily to reach Ethiopia, died in Cairo in 1782. The Brethren remained in Egypt until $1783 .{ }^{28}$

are described in Bechler, Die Herrnhuter in Ägypten, 25, 81-86 and in Cranz, Alte und neue Brüder-Historie, 677-678.

26 Cf. Hutton, $A$ History, 162.

27 On the use of the lot by the Moravian Brethren, see: Elisabeth Sommer, "Gambling with God. The Use of the Lot by the Moravian Brethren in the Eighteenth Century," Journal of the History of Ideas 59, no. 2 (1998): 267-286.

28 The publications of the project "Quellen zu Ägypten der Herrnhuter Brüderunität" mentioned in note 5 are a precious testimony to the activities in Egypt until they left in 1783 . 
The manuscript preserved as R.17.B.7.b.3 and reproduced in the Appendix is the letter of recommendation written by the patriarch to the metropolitan of Ethiopia and given to Hocker on the 1oth of September 1756 (see section 2.2). ${ }^{29}$ In that year, the Ethiopian emperor was Iyo'as I (r. 1755-1769) and the metropolitan of Ethiopia was Abunä Yoḥannəs III. Yoḥannəs III had been designated by the Coptic Synod and consecrated by the Coptic Orthodox Pope Yoannis XVII in 1744 but was only able to reach Ethiopia and assume his functions in $1745^{30}$

The manuscript consists of two longitudinal sheets glued together and shows traces of wax and glue. The two sheets were glued together between lines 24 and 25 where one can see the catchwords اخوتهم المسيحيين "their fellow Christians" ending the first sheet and repeated at the beginning of the second. On the left and on the right upper parts, the manuscript bears the seal of the Coptic patriarch where one can read in Coptic ic xc, the abbreviation for Jesus Christ, followed by the name of Patriarch Mapkoc and the abbreviations $x \mathrm{c}$ and $\Theta c$, respectively, corresponding to "Lord" and "God." Two crosses appear in the middle over and under the name of the patriarch.

On the left upper part and right above the seal featuring the word маркос, two words are written, one in Coptic reading cimгळn "Sim'on," the birth name of the patriarch, ${ }^{31}$ followed underneath by the mention (in Arabic) المدعَ' which means "called." This gives us the following reading: "Simeon, called Markos." The Basmala ${ }^{32}$ wording reading b-ismi-llāhi al-ra'üfi al-rahīmi as used by the Christians ${ }^{33}$ and followed by b-llähial-halās "in God is salvation" cover two lines written in calligraphy between the two seals.

29 According to R.17.B.6.a.14.g. preserved at the Herrnhut Archives and cited by Manukyan, Konstantinopel und Kairo, 3 oo.

30 Cf. Salvatore Tedeschi, "Ethiopian Prelates (d. 1699-d. 1761)," in The Coptic Encyclopedia 4 (1991): 1005a-1044a; Marius Chaîne, La chronologie des temps chrétiens de l'Égypte et de l'Éthiopie (Paris: Geuthner, 1925), 247, 270.

31 Cf. Antoine Khater and Oswald Khs-Burmester, ed., History of the Patriarchs of the Egyptian Church known as the History of the Holy Church of Sawirus ibn al-Muqaffa, Bishop of el-Ashmunein. Vol. 3,3, Cyril II-Cyrilv (AD 1235-1894) (Cairo: Société d' Archéologie Copte, 1970), 292-295.

32 For a definition of the Basmala, see: William Graham, "Basmala," in Encyclopaedia of Islam, THREE, URL: http://dx.doi.org/10.1163/1573-3912_ei3_COM_23497 (26.o1.2019).

33 For a discussion of the Basmala as written by the Christians, see: Karin Almbladh, "The 'Basmala' in Medieval Letters in Arabic Written by Jews and Christians," Orientalia Suecana 59 (2010): 56-59. 
The content follows and covers another 48 lines. In what follows, I reproduce the Arabic wording of the whole letter and provide an English translation: ${ }^{34}$

34 The edition and the translation are slightly revised versions of what appears in ElhageMensching, Pope Mark VII, 44-49. For the purpose of the present article, I substituted the original punctuation marks with modern ones in the English translation and made some minor changes for a better understanding of the text. 


$$
\text { بالله الخلاص الله الرؤوف الرحيم }
$$

من مرقصَ. عَبد عبيد الرب يَّوعَ المَسِيحَ.المدعَوا

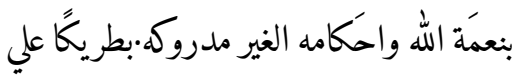
مدينة العَظما الأْكند ريه.والمدينه المحبَه الله الايروشاليميه.والديار المصريه.وساير الهين

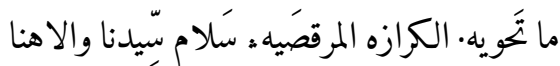

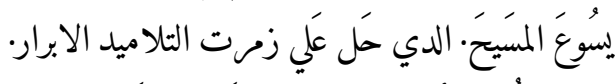

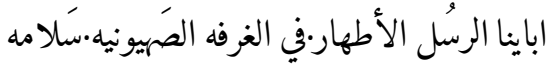
10 يفيض دلك.ويتضاعَف ويتزايد ويترادف. عَلي اخينا الحَبيب.الفاضل اللبيب:ء المويد من الله.

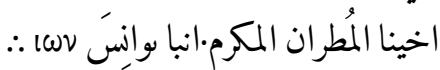
مُطران الحَبشه.بارك الله عليه.وَعلى شَعَبه

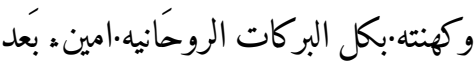
تجديد البركات عَليه.واهدي السَّلام الروحَانيه لديه.الموجب لاصدارها اليه.هوان المماتل بحملها.الابن المبارك.الشماسْ المكرم.ايرينيوسْ.

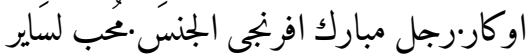
20 انه يتفرج عَلي بلاد الحجَشه.فكتبنا لكم هدا النصَ.لاجل ما تشملوه بنظركم.لان المدكور

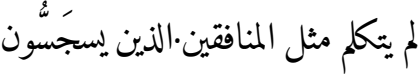
اخوتهم المسيَحَين :..........

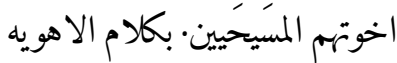


In the name of the clement and merciful God.

In God is salvation.

From Marqoș, the servant of the servants of Jesus Christ, called with God's grace and his unknown wills, Patriarch of the great city of Alexandria and the God loving city of Jerusalem and the Egyptian territories and all what is included in the Episcopate of Saint Mark. May the peace of our Lord and God Jesus Christ that came upon the assembly of innocent disciples, our fathers the pure apostles in the house of Sion, the peace

10 that He told them would be upon them for ever and ever embrace, grow, increase and extend upon our beloved virtuous wise brother, supported by God

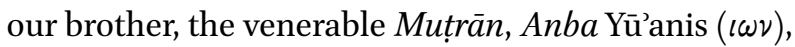
Muțrān of Habaša. God bless him, his people

15 and his priests with every spiritual blessing, Amen. After reiterating the blessings upon him and wishing him the spiritual peace expressed herein, this [letter] I entrusted to be carried by the blessed son and venerable deacon Irenaeus Hocker, a blessed man of European race, loving (to) the rest of Christians and all God's creatures, who informed us of his intention to see the land of Habaša. So we wrote to you this text so that you welcome him because his speech is not that of the hypocrites who upset their fellow Christians $\therefore \therefore \therefore$....

their fellow Christians with words false 


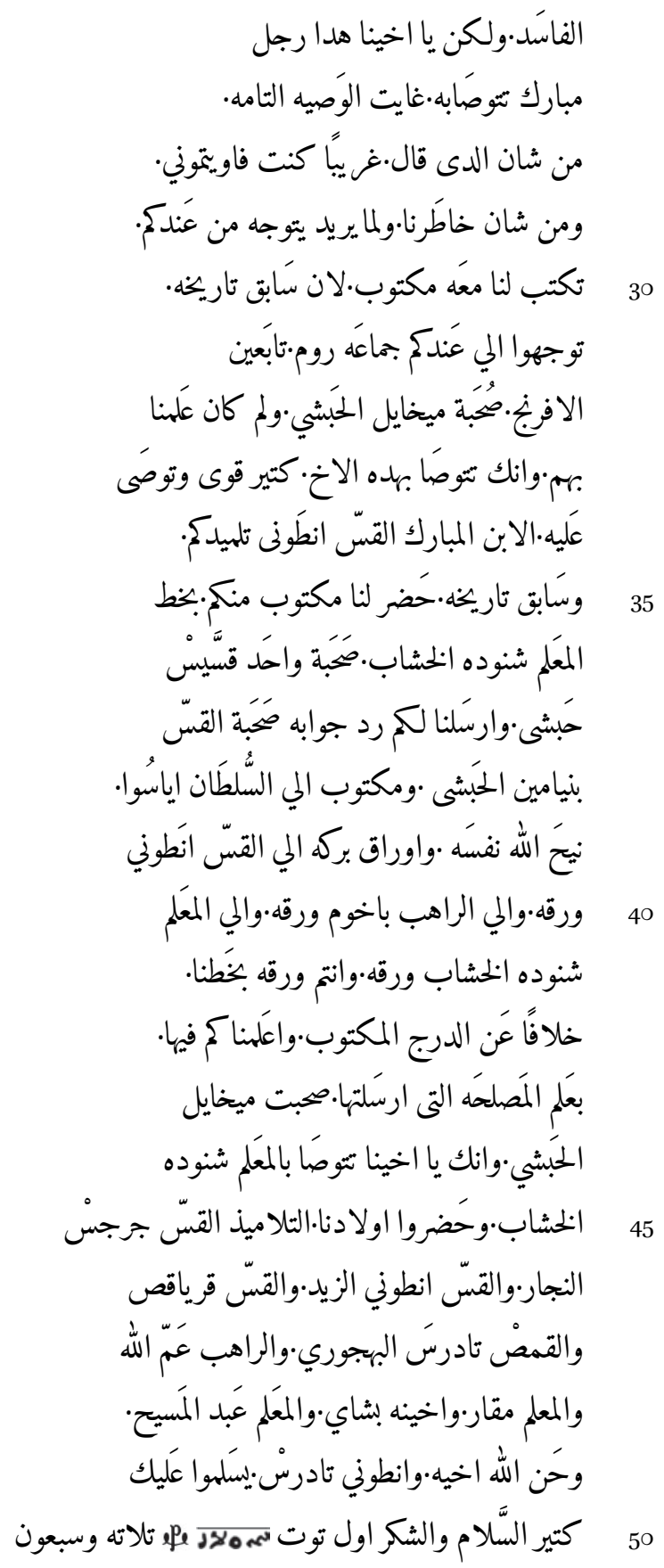


and corrupt. But, my brother, this is a man who is blessed and you take the utmost care of him for the sake of the one who said "I was a stranger and you welcomed me" and for our sake. And when he will want to depart from you write to us a letter [to take] with him because in the past. Greeks came to you, followers of the Europeans, along with Mīhāyil al-Ḥabašì and we were not aware of it. And take the utmost care of this brother and recommend him to the blessed son, the priest Anțūnī, your student. And in the past, we received a letter from your side written by múallim ${ }^{35}$ Šenūda al-Hुašāb brought by an Ethiopian deacon, and we sent you a reply with the priest Benyāmīn al-Ḥabašì and a letter to the Emperor Iyāsū —-may God rest his soul—himself and blessing notes, to the priest Anțūnī a note, and to the monk Bāhūm a note, and to mu'allim Šenūda al-Huš̌āb a note, and to you a note of our writing, unlike what is usually written. And we informed you therein, being aware of the issue you entrusted to Mīhāyil al-Ḥabašì, and that you, our brother, take care of múallim Šenūda al-Hašāb. And [there] are present our children, the students, the priest Ğerğes

al-Nağğār, and the priest Anțūnī al-Zīd, and the priest Qeryāqoṣ, and the hegumen Tādros al-Bahğūrī, and the monk 'Ammallāh and mu'allim Maqār, and his brother Bešāy, and mu'allim 'Abdalmasīḥ, and Ḥannallāh his brother, and Anțūnī Tādros who send you their best regards and thanks. The first of Tout 1473 Anno Martyrum seventythree [= September 9, 1756 Anno Domini] . 
Lines 3 to 7 are dedicated to the name and title of the patriarch, followed in lines 7 to 11 by an invocation of blessings upon the addressee of the letter, who is described in line 12 as "beloved and virtuous brother" and named Mutrān in lines 13 and 14, meaning "metropolitan" in Arabic, followed by the denomination Anba Yü’anis (= Abunä Yoḥannəs) and again Mutrān of Habaša, meaning Ethiopia. In expressing his blessings to the metropolitan of Ethiopia in lines 15 and 16, the patriarch paraphrases the Epistle to the Ephesians 1:3, "Blessed be the God and Father of our Lord Jesus Christ, who has blessed us in Christ with every spiritual blessing in the heavenly places."

The formulae of greeting end in line 15 with the word Amen. The recommendation proper of Friedrich Hocker, who is referred to as Irenaeus, starts in line 17. Hocker is described as a blessed and venerable deacon of European race and as a person who loves his fellow Christians. Further on, in lines 23 and 24, the patriarch underlines the fact that Hocker is nothing like the hypocrites who upset their fellow Christians, using in his writing the verb لِسجَسَّون , "to upset," "to turn upside down" in the same structure and almost the same words as a passage from the Apocryphal Acts of Bartholomew and Andrews, which reads "لا تسمعوا من كلام هولاى الخالفين الذين يسجسون المسكونة" "Hearken not on unto the speech of these seditious men, who have turned the world upside down."36

The letter goes on in lines 25 and 26 with the repetition of the catchwords "fellow Christians" and the end of the sentence "with words false and corrupt." Here, the letter shows already the first signs of the benevolent attitude of the patriarch of the Copts towards Hocker and the community that he represented. The patriarch seems convinced that the community of the Brethren is sincere, not like the "hypocrites who upset their fellow Christians with words false and corrupt" hinting to the Catholics and Greeks and to the previous attempts to convert the Ethiopians to Catholicism. From the words of the patriarch, it seems that Hocker was successful in convincing him of the benevolent character of his mission. Here one should note that the mission of the Brethren was based on unintrusiveness as they believed that God positively wills the existence of a variety of churches to cater for different spiritual needs and that there was no need to win converts from other Christian churches. Their presence was also based on fellowship and giving an example of virtuous and useful life.

${ }_{3} 6$ Agnes Lewis, Acta Mythologica Apostolorum. Transcribed from an Arabic Ms in the Convent of Deyr-Es-Suriani, Egypt, and from Mss in the Convent of St Catherine on Mount Sinai with two Legends from a Vatican $M s$ by Prof. Ignazio Guidi, and an Appendix of Syriac Palimpsest Fragments of the Acts of Judas Thomas from Cod. Sin. Syr. 30 (London: Clay, 1904), 17 [= f. $34^{\mathrm{r}}$. 
In lines 27 and 28, the patriarch recommends that Hocker be welcomed, quoting Mt 25:35, "I was a stranger and you invited me in," and seems moreover to trust him as he ends this part of the letter by asking the metropolitan to send him a letter that Hocker would bring him when he would leave Ethiopia to return to Cairo (line 30). Lines 35 to 45 of the letter are dedicated to the contact of the two prelates in the past, which seems not to have been always fortunate, with the mention of various persons I had not had the opportunity to further investigate. This passage is rather obscure and would need more research in the future.

In lines 45 to 49 , the patriarch mentions all the persons who join him in sending their regards to the metropolitan and he ends his letter, using the Coptic month and year dating, writing in Arabic the first of Tout, corresponding to the 1oth of September, and using the zimām ${ }^{37}$ numerals to indicate the year 1473 Anno Martyrum corresponding to 1756 Anno Domini. Anno Martyrum is represented in the Arabic text by the symbol of the Coptic Era of Martyrs.

The objective of this letter was never achieved, Friedrich Hocker was never able to meet the addressee of the letter of recommendation in person and the addressee never received the letter.

\section{4}

\section{Conclusion}

The three Arabic letters preserved in the Herrnhuter archives represent landmarks with regard to the relinquished mission to Ethiopia. The first letter (see section 2.2) was the first letter ever written by the Coptic patriarch to Count von Zinzendorf. It was a letter of introduction of the Brethren aiming at establishing the first contact with the Coptic patriarch. The letter of recommendation addressed to the metropolitan of Ethiopia, which we have just looked at in some detail, was meant to facilitate the contact with the Ethiopian Church, which was the primary goal of the Herrnhuter.

The third letter which I briefly mentioned at the beginning of section 2.3 and which was not further discussed in this paper was addressed by the Cop-

37 The zimām numeral system or hurüf al-zimām developed in Egypt from the register's numerals. Unlike the classical Coptic system, the signs are cursive minuscule letters rather than uncial ones. After the twelfth century, Coptic Christians continued to use zimām numerals in documents otherwise written in Arabic. Cf. Stephen Chrisomalis, Numerical notation. A Comparative History (Cambridge: Cambridge University Press, 2010), 149-151; George Colin, "De l'origine grecque des chiffres de Fès et de nos chiffres arabes," Journal Asiatique 222 (1933): 193-215. 
tic patriarch to Zinzendorf, stating that the patriarch sees that the Brethren's faith is close to the faith of the Copts but requests more information about the kind and origin of the Christian confession of the Brethren. The fact that only copies of this third letter are preserved in the archives at Herrnhut, is a direct consequence of the failed attempt to reach Ethiopia, since Hocker must have lost the original during the shipwreck. ${ }^{38}$

Although the Herrnhuter mission to Ethiopia finally never took place, the episode described in this article can be seen as a small piece of the puzzle of deconstructing the view on Ethiopian Christianity as forgotten by the rest of the world. Count Zinzendorf's vision of an Ethiopian mission and the extreme effort of the Herrnhut brethren during several years to reach Ethiopia testify to an immense interest in establishing contact and interaction with what they considered fellow Christians in the far-away country. The letter of recommendation shows the Coptic patriarch in Cairo as an intermediator of this endeavour, so that the triangle Herrnhut-Cairo-Ethiopia is an interesting example of a kind of global interconnection, which unfortunately was not put into practice.

$3^{8}$ Cf. Elhage-Mensching, Pope Mark VII, $5^{8 .}$ 


\section{Appendix}
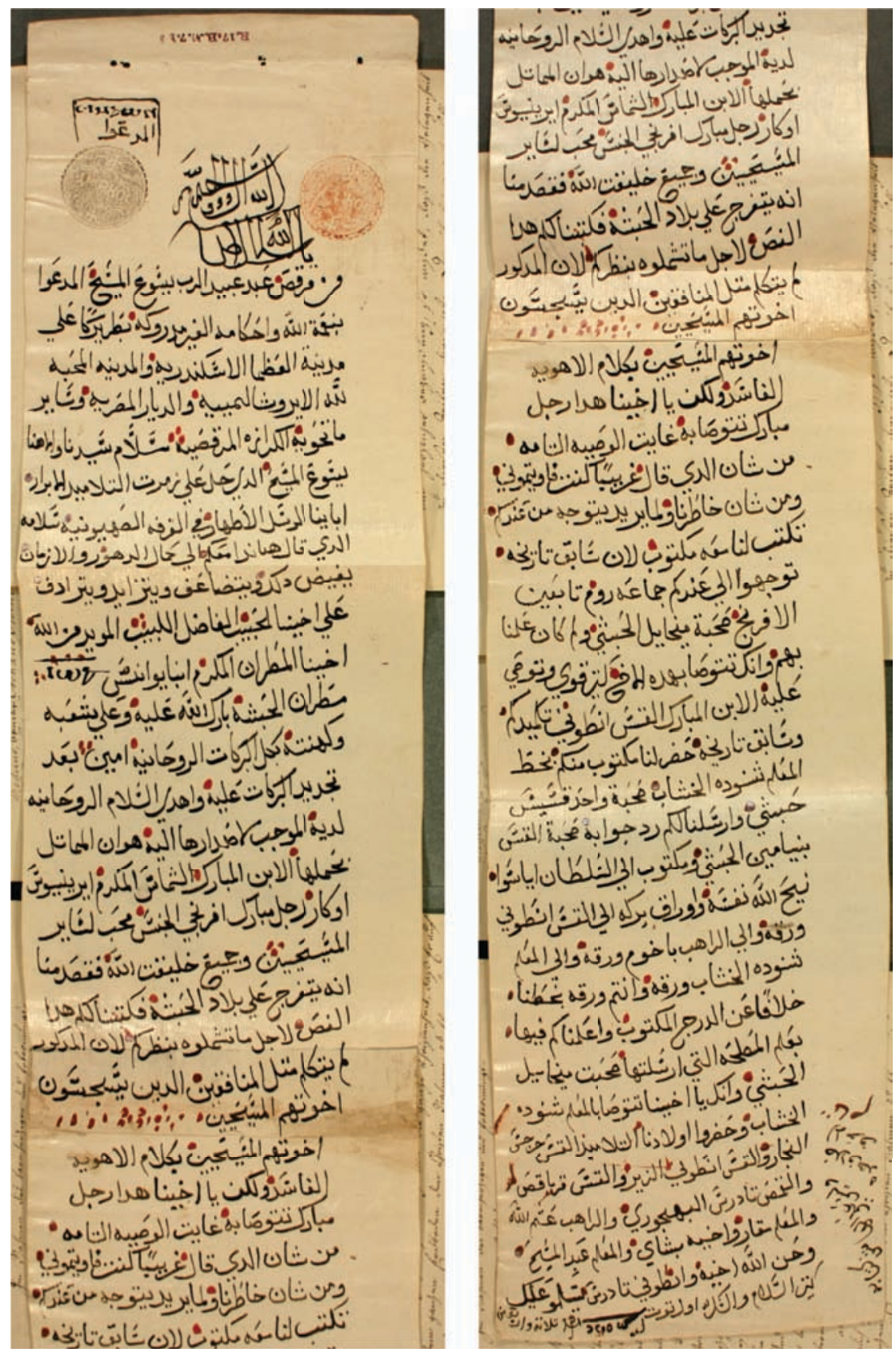

FIGURE 8.1 Ms. R.17.B.7.b.3

UNITÄTSARCHIV HERRNHUT 


\section{List of References}

Almbladh, Karin. "The 'Basmala' in Medieval Letters in Arabic Written by Jews and Christians." Orientalia Suecana 59 (2010): 45-6o.

Bechler, Theodor. Die Herrnhuter in Ägypten. Evangelisation und Mission der Herrnhuter Brüder in Ägypten im 18. Jahrhundert und ihr Vorstoß nach Abessinien. Herrnhut: Verlag der Missionsbuchhandlung, 1936.

Brethren's Society for the Furtherance of the Gospel, ed. Periodical Accounts relating to the Missions of the Church of the United Brethren established among the Heathen. Vol. 12. London: John Marshall, 1831.

Chaîne, Marius. La chronologie des temps chrétiens de l'Égypte et de l'Éthiopie. Paris: Geuthner, 1925 .

Choules, John, and Thomas Smith. The Origin and History of Missions. Compiled and Arranged from Authentic documents. Vol. 1. Boston: S. Walker, 1832.

Chrisomalis, Stephen. Numerical notation. A Comparative History. Cambridge: Cambridge University Press, 2010.

Colin, George. "De l' origine grecque des chiffres de Fès et de nos chiffres arabes." Journal Asiatique 222 (1933): 193-215.

Cranz, David. Alte und neue Brüder-Historie oder kurz gefaßte Geschichte der evangelischen Brüder-Unität in den älteren Zeiten und insonderheit in dem gegenwärtigen Jahrhundert. Barby: Laux, 1772.

Elhage-Mensching, Lina. "Wie kommt man nach Äthiopien? Patriarch Markos vir. (r. 1745-1769), Abuna Johannes III. (r. 1747-1761) und Ireneos Hocker (1713-1782)." In Imaginiert und real, erschaut und erdacht. Literarische Werke von und über Christen in Ägypten, edited by Martin Tamcke and Heike Behlmer, 79-88. Wiesbaden: Harrassowitz, 2017.

Elhage-Mensching, Lina. Pope Mark VII. Arabic Letters to Count von Zinzendorf and Yohannes III, Metropolitan of Abyssinia, with the 'Sermon on the True Faith' in an Appendix. Baden-Baden: Ergon, 2020.

Graham, William. "Basmala." In Encyclopaedia of Islam, THRE E. URL: http://dx.doi.org/ 10.1163/1573-3912_ei3_COM_23497 (26.01.2019).

Hamilton, Taylor, and Kenneth Hamilton. History of the Moravian Church, the Renewed Unitas Fratrum. Bethlehem, PA: Interprovincial Board of Christian Education Moravian Church in America, 1967.

Hutton, Joseph. A History of the Moravian Missions. London: Moravian Publ. Office, 1922.

Hutton, Joseph. A History of the Moravian Church. 2nd ed. London: Moravian Publ. Office, 1909 .

Khater, Antoine, and Oswald Khs-Burmester, ed. History of the Patriarchs of the Egyptian Church known as the History of the Holy Church of Sawirus ibn al-Muqaffa, 
Bishop of el-Ashmunein. Vol. 3,3, Cyril II-Cyril V (AD 1235-1894). Cairo: Société d'Archéologie Copte, 1970.

Lane, Edward W. Arabic-English Lexicon. London: Williams \& Norgate, 1863.

Lewis, Agnes. Acta Mythologica Apostolorum. Transcribed from an Arabic $M$ s in the Convent of Deyr-Es-Suriani, Egypt, and from Mss in the Convent of St Catherine on Mount Sinai with two Legends from a Vatican Ms by Prof. Ignazio Guidi, and an Appendix of Syriac Palimpsest Fragments of the Acts of Judas Thomas from Cod. Sin. Syr. 3o. London: Clay, 1904.

Manukyan, Arthur. Konstantinopel und Kairo. Die Herrnhuter Brüdergemeine im Kontakt zum Ökumenischen Patriarchat und zur Koptischen Kirche. Interkonfessionelle und interkulturelle Begegnungen im 18. Jahrhundert. Würzburg: Ergon Verlag, 2010.

Munro-Hay, Stuart. Ethiopia and Alexandria: The Metropolitan Episcopacy of Ethiopia. Warsaw: ZAS PAN, 1997.

Raineri, Osvaldo. "Yoḥannəs [III]." In EAe 5 (2014): 71-72.

Sommer, Elisabeth. "Gambling with God. The Use of the Lot by the Moravian Brethren in the Eighteenth Century." Journal of the History of Ideas 59, no. 2 (1998): 267-286.

Strauss, Peter, ed. The Fetha Nagast. The Law of Kings, translated by Abba Paulos Tzadua. Addis Abeba: Haile Selassie University, 1968.

Tamcke, Martin, and Arthur Manukyan, ed. Herrnhuter in Kairo. Die Tagebücher 17691783. Würzburg: Ergon Verlag, 2012.

Tamcke, Martin, Arthur Manukyan and Christian Mauder, ed. Die arabischen Briefe aus der Zeit der Herrnhuter Präsenz in Ägypten 1770-1783. Würzburg: Ergon Verlag, 2012.

Tedeschi, Salvatore. "Ethiopian Prelates (d. 1699-d. 1761)." In The Coptic Encyclopedia 4 (1991): 1005a-1044a. 